\title{
KEELE KESTLIKKUSE JA KAO KONSTRUEERIMINE POOLAVALIKES DISKURSUSTES
}

\author{
Kadri Koreinik, Kristiina Praakli
}

Ülevaade. Artikli peaeesmärk on analüüsida keele kestlikkuse ja kao diskursiivset konstrueerimist Saksamaa ja Soome eestlaste ning setu ja võru keele kasutajate poolstruktureeritud intervjuude näitel. Intervjuuandmestik pärineb koostööprojektist European Language Diversity for All (ELDIA), mille keskmes on väikese kõnelejaskonnaga soome-ugri keeled tänapäeva mitmekeelsetes ühiskondades. Saksamaal ja Soomes elavad eestlased esindavad allohtoonseid keelerühmi; setu- ja võrukeelsed moodustavad autohtoonsed Eesti keelekogukonnad, mille piiritlemine pole probleemitu. Kõigi nimetatud kogukondade puhul on tegu mitmekeelsete eestlastega, kes on suuremal või vähemal määral säilitanud oma vähemuskeele enamuskeelses, vastavalt saksa-, soome- ja eestikeelses keeleruumis. Diskursusanalüüsi kõrval vaadeldakse põgusalt, kuidas hindavad oma keeleoskust erinevas vanuses inimesed. Kogu keelekestlikkuse ja -kao diskursus on vaadeldav legitimatsioonidiskursusena, kus osalised argumenteerivad vähemuskeelte funktsioonide ja tuleviku üle. Ühe põhitulemusena võib esile tuua, et kõik vaadeldud keelekogukonnad püsivad keelelise või kultuurilise rikastamise diskursiivses raamistikus.

Võtmesõnad: vähemuskeel, enamuskeel, vahendajakeel, keelekogukonnad, diskursusuuringud, keeleideoloogia, keeleökoloogia, eesti keel, inglise keel

\section{Sissejuhatus}

Artiklil on kaks eesmärki. Peaeesmärk on analüüsida keele kestlikkuse ja kao diskursiivset konstrueerimist Saksamaa ja Soome eestlaste ning setu ja võru keele kasutajate poolstruktureeritud intervjuudes. Teine eesmärk on tutvustada põgusalt rahvusvahelist valdkondadevahelist projekti ELDIA ${ }^{1}$ ja selle raames saadud andmeid.

Vt http//:www.eldia-project.org (03.03.2013). 
Keelelise mitmekesisuse põhjustena tuuakse sageli välja just imperialismi/ kolonialismi, kommunikatsiooni ja rände kasvu, identiteedi fragmenteerumist, vähemuskeelte (taas)sündi ning hariduse, ennekõike võõrkeelte õppe levikut (Myers-Scotton 2002, Cenoz jt 2011). Mõned neist nähtustest on vastutavad ka teise globaalse ilmingu, inglise keele leviku eest. Global English või World Englishes domineerimine on viinud sinnamaani, kus seni vähemuskeeltele kavandatud keelehoiumeetmete järele tuntakse vajadust ka riigikeelte, ennekõike väikekeelte puhul (Ehala 2010). Sageli kasutatakse analoogiat biosfääriga: kui keel ei suuda kohaneda tänapäeva muutuva keskkonnaga, võib teda pidada ohustatud keeleks (Maffi 2000, Mufwene 2008). Globaalsed muutused on teisendanud keelte ülesandeid nii riikide kui etnoste vahel ja sees, lisades suhtlusesse ja kontaktsituatsioonidesse uusi dimensioone, mis varem või hiljem panevad proovile keelte, eriti väikekeelte kestlikkuse. Nii puutub üha suurem osa inimesi kokku uute keeltega ja on sunnitud tegema keerulisi valikuid, näiteks kas hoida või vahetada keelt. Laste eest teevad paraku keelevalikuid lapsevanemad, kel on keeleülekandes võtmeroll (Fishman 2001). Keelte vastastikune toimimine, aga ka poliitika ja majanduse mõju keelekasutusele on nii sotsiolingvistide kui keeleökoloogia ja -poliitika uurijate järjest suureneva tähelepanu all. Viimased on võtnud kasutusele näiteks etnograafilisi ja ka diskursusanalüüsist tuntud meetodeid, avardades nii keelepoliitika horisonti (Johnson 2009, Hult 2010, McCarty 2011).

Artikli ülesanne ongi näidata, kuidas konstrueerivad keele kestlikkust ja kadu, s.t millisena näevad vähemus-, enamus- ja vahendajakeelte tähtsust ja tulevikku Saksamaal ja Soomes elavad eestlased ning setu ja võru keele kasutajad Eestis ${ }^{2}$. Artikkel on loogiline jätk autorite varasemale uurimistööle, kus vaatluse all on olnud väliseesti keel, mitmekeelne keelekasutus, eesti keele kestlikkus Tampere eesti kogukonna näitel (Praakli 2007, 2009, 2013a, 2013b) ja keeleideoloogiad avalikus diskursuses (Koreinik 2011a).

\section{Uuritavatest keelekogukondadest ELDIA raamistikus}

ELDIA kõige laiem ning ühtlasi ambitsioonikam eesmärk on individuaalse ja sotsiaalse mitmekeelsuse ümberhindamine, ümbermõtestamine ja edendamine. Projekti keskmes on väikese kõnelejaskonnaga soome-ugri keeled tänapäeva mitmekeelsetes ühiskondades. Kaheksat Euroopa ülikooli siduva võrdlusuuringu peamine eesmärk on piirkonna- ja rahvuskeelte ning rahvusvaheliste vahendajakeelte enamikel juhtudel inglise keele - vastastikuse toimimise, aktiivse keelekasutuse ja keelevalikute kirjeldamine ning analüüsimine Euroopa erinevates keelekeskkondades soome-ugri keelte kontaktsituatsioonide näitel. Nendeks keelteks on vepsa ja karjala keel Venemaal, ungari keel Austrias ja Sloveenias, meä ja rootsisoome keel Rootsis, kveeni ja põhjasaami keel Norras, võru ja setu keel Eestis ning eesti keel Soomes ja Saksamaal. Uuritavad soome-ugri keeled kirjeldavad hästi väikekeelte globaalset seisundit, aga ka nende keelte kontaktsituatsioone ja kõnelejate mitmekeelsust. Ühtlasi esindavad need erinevaid poliitilisi ja majanduslik-ühiskondlikke olusid. Uuritavate keelte hulgas on nii põliseid vähemuskeeli nagu karjala või vepsa

2 ELDIA kontekstis on vähemuskeeled eesti keel Saksamaal ja Soomes, setu ja võru keel Eestis, enamuskeeled on saksa ja soome keel Saksamaal ja Soomes, eesti keel Eestis. Vahendajakeel (ingl vehicular language) on kõikides sihtmaades inglise keel. 
keel kui ka alles kujunemisel olevaid, hilistekkelisi kogukondi, mida esindavad eesti kogukonnad Soomes ja Saksamaal.

Järgnevalt anname põgusa ülevaate uuritavatest keelekogukondadest. Kogukondade detailsema kirjelduse ning viited kirjandusele võib leida ELDIA uurimisraportitest (Koreinik 2013a, 2013b, Praakli 2013a, 2013b).

Saksamaal ja Soomes elavad eestlased esindavad allohtoonseid ehk väljaspool asukohamaa geograafilist ruumi kujunenud keelekogukondi. Kummagi riigi eestikeelsete kogukondade näol pole tegu põliste või pikkade traditsioonidega keelerühmadega, vaid eri põhjustel kujunenud n-ö hilistekkeliste sisserännanute rühmadega, kelle tekkelugu saab alguse Teise maailmasõja aastatest (eeskätt Saksamaa puhul) või Eesti Vabariigi taasiseseisvumisest. Eestikeelsed kogukonnad neis riikides erinevad nii kõnelejaskonna sotsiodemograafilise tausta, (võõr)keeleoskuse kui väljarände motiivide poolest.

Saksamaa Statistikaameti andmetel elas 2011. a lõpus riigis 4840 inimest, kelle päritoluriigiks on Eesti Vabariik. ${ }^{3}$ Soome eestikeelse elanikkonna arv on paarikümne aastaga suurenenud paarikümnekordselt. Kui 1990. a elas Soomes 1394 eesti keelt emakeelena rääkijat, siis 2004. aastaks oli nende arv tõusnud juba 13784ni (vt Kyntäjä 1997, Laanekask 2006, Praakli 2009). Eestlaste eeskätt töömotiividest johtunud väljaränne Soome intensiivistus Euroopa Liidu idalaienemise järel. Soome Statistikaameti uuematel andmetel elab Soomes juba ligi 33076 emakeelena eesti keele kõnelejat. ${ }^{4}$ Kui Soomes moodustavad emakeelena eesti keele kõnelejad venekeelse uusvähemuse järel suuruselt teise vähemusrühma, siis Saksamaa kirevas keeleruumis on eesti kogukond üks väiksematest. ${ }^{5}$

Enamik nii Soomes kui Saksamaal elavatest eestlastest on sisserännanute rühmadele tüüpiliselt koondunud suurlinnadesse või nende lähiümbrusesse (Soomes Helsingi, Vantaa, Espoo, Tampere, Turku; Saksamaal Berliin, Hamburg, München). Saksamaal domineerivad Eesti kodanike seas naised vanuses 25-40 eluaastat. Ka Soomes on naiste osakaal praegu veel suurem, kuid nooremates vanuserühmades (25-40) on ülekaalus mehed (Praakli 2013a, 2013b).

Setu ja võru keele kasutajaid võib pidada põlisteks Eesti keelekogukondadeks, kuid setude etniline määratlemine pole probleemitu. Mõlemal juhul on siiski tegu kakskeelsete eestlastega, kes eesti keele standardiseerumise edenedes ja ühiskeele tugevnedes on säilitanud oma kohapealse kõnepruugi ning suuremal või vähemal määral identifitseerivad ennast lokaalselt (Eichenbaum, Pajusalu 2001). Lõunaeesti murded on kõige paremini säilinud just Kagu-Eesti perifeerias (Pajusalu jt 1999), mida võib pidada Eesti rikkaimaks kultuuriperifeeriaks (Krikmann 2000).

Ajalooliselt on setud elanud Eesti kaguosas Eesti-Vene piiril, nende keel liigitatakse traditsiooniliselt Võru murde hulka (Pajusalu jt 2002, Pajusalu 2007). Uusajal on setude asuala rahvastik kõikunud; ränne tänapäeva Eesti alale ja alalt ning piirimuutused pole setude (identiteedi) kujunemisloos olnud sugugi väheolulised (Saar 2003). Kui Eestis ei peeta setusid vähemusrahvuseks, siis Vene Föderatsioonis on nad hiljuti arvatud Venemaa põliste väikerahvaste ühendnimistusse. ${ }^{6}$ 2011. aasta rahva ja eluruumide loenduse andmed näitasid, et Setu murraku kasutajaid on üle 12500 (REL07). Seega peaks oluline osa setu keele oskajaid elama väljaspool Setumaad. Alates 1990ndatest on setud olnud poliitiliselt aktiivsed. Nn setu liikumise

\footnotetext{
3 http://de.statista.com/statistik/daten/studie/1221/umfrage/anzahl-der-auslaender-in-deutschland-nachherkunftsland/ (06.07.2012).

4 www.stat.fi (30.09.2012).

5 https://www.destatis.de/DE/PresseService/Presse/Pressemitteilungen/2011/09/PD11_355 122.html (06.07.2012).

6 Pravitel'stvo Rossijskoj Federacii. Postanovlenie ot 24 marta 2000 g. N 255. O edinom perečne korennyh

maločislennyh narodov Rossii. http://www.minnac.ru/minnac/info/13884.html (03.03.2013).
} 
poliitilisi eesmärke - ühtset Setumaad Eesti Vabariigi koosseisus ja setu kultuuri kestlikkust ja arengut - on erinevad aktivistid erinevalt tähtsustanud (Eichenbaum 1998). Samas on setu aktivistide tegevus traditsioonilise identiteedi, kultuuri ja keele säilitamiseks panustanud hegemooniliste kultuuripraktikate konstrueerimisse (vt Annist 2009).

Ka võru keelt peetakse konventsionaalselt eesti keele murdeks, võrukeelseid ei positsioneeri vähemusena ei kasutajad ise ega ka uurijad. Nii on keelekogukonna suuruse hindamine selgete ja konsensuslike definitsioonide puudumisel keeruline. Viimase rahvaloenduse andmetel on ennast Võru murde (sh Setu murraku) kasutajatena määratlenud üle 87000 eesti emakeelega püsielaniku. Võrokeste keelevahetuse kõrghetk jääb ilmselt 1960.-1980. aastatesse (Org jt 1994).

Alates 1980. aastate lõpust on üritatud keelevahetust pöörata: muuhulgas on võru ja setu aktivistid püüdnud oma keelekujudele keele staatuse saamiseks korduvalt, kuid tulutult keeleseadust muuta. Muudatusettepanekute tagasilükkamise põhjuseid võib otsida eesti keele ohustatuse diskursusest (Koreinik 2011b), mille keskmes representeeritakse eesti keelt peamiselt vene keele, aga ka inglise keele tõttu ohustatuna.

\section{Teoreetilis-metodoloogiline kontekst: keeleideoloogiad ja -ökoloogia ning diskursusanalüüs}

Käsitame keeleideoloogiat kui keelt ja keelepraktikaid hierarhiliselt positsioneerivate diskursiivsete praktikate tulemust (nt Silverstein 1979, Blackledge 2005). Keeleideoloogiad on keelepoliitikast ja keelepraktikatest makrotasandi sotsiolingvistikas varasemalt selgelt lahus hoitud (Ferguson 1977), teisalt on keeleideoloogiaid ja keelepraktikaid peetud ka keelepoliitika objektideks (Spolsky, Shohamy 2000). Milline on aga täpselt nende kolme nähtuse vahelise seose suund, on raske öelda, ent koos varjatud keelepoliitika mõiste kasutuselevõtu ja keelepoliitika etnograafilise uurimismeetodi levimisega on kõik kolm võrdselt olulised ja suureneva tähelepanu all. Thomas Ricento ja Nancy Hornbergeri (1996: 420) arvates on indiviidide igapäevane suhtlus nende viis väljendada, töötada välja, vaidlustada, tõlgendada ja analüüsida keelepoliitikat. Keelepoliitikaks peavad nad sedagi, millise keele indiviidid suhtluses valivad, kuidas suhtluspartneri poole pöördutakse, milline on indiviidide kehakeel ja millest räägitakse. Ka keeleökoloogia uurimissuunana (mitte-metoodikana) analüüsib seda, mil moel keeled ühiskonnas positsioneeruvad. Vähem tuntud on keelepoliitika ökoloogiline analüüs, mille üks keskne küsimus on keelepoliitikate suhe indiviidide keelekasutuse kogemuste ja uskumustega keelte suhtes (Hornberger, Hult 2008).

Diskursusuuringutel (ingl discourse studies) on mitmeid suundi (Jørgensen, Phillips 2002). Artiklis oleme intervjuutulemuste analüüsis kasutanud tuttavamat, kriitilist diskursusanalüüsi (Fairclough 1989, van Dijk 2005, van Leeuwen, Wodak 1999). Viimane eristab diskursustes nelja tüüpi makrostrateegiaid: konstruktiivsed (constructive), alalhoidvad-õigustavad (strategies of perpetuation and justification), transformeerivad (strategies of transformation) ja destruktiivsed (destructive). Alalhoidvad-õigustavad strateegiad toetavad ja taastoodavad näiteks rahvusidentiteeti (de Cillia jt 1999). Kuigi tänapäevalgi on mitmekeelsus pigem reegel 
kui erand, ei ole ligi pooled eurooplased aktiivselt mitmekeelsed, vaatamata koolis õpitud võõrkeeltele (üldjuhul inglise keel) (Cenoz jt 2011, Special Eurobarometer 386). Vähemuskeelte kasutajatele aga on inglise keel kolmas või neljas keel (Cenoz, Gorter 2005). Kuna keeltele omistatakse erinev tähendus, tunnetavad vähemus- ja väikekeelte kasutajad enamuskeelses keskkonnas, et nad peavad oma erinevust põhjendama või koguni õigustama. Seega on keelekestlikkuse ja -kao konstrueerimine intervjuudes vaadeldav (mitte küll spontaanse) legitimatsioonidiskursusena (vrd van Dijk 2005).

Kõige tavalisem intervjuude uurimise meetod on informantide poolt öeldu taandamine sisukategooriateks ja informatsiooni koondamine erinevate teemade alla (Abell, Myers 2008). Teine võimalus on näha intervjuudes ennekõike interaktsiooni osaliste, intervjueerija ja informandi strateegilist vooruvahetust. Oleme siin valinud esimese tee, keskendudes rohkem sellele, mida intervjuudes öeldi, mitte niivõrd sellele, kuidas seda tehti. Poolavaliku diskursuse uurimine võimaldab jälgida erinevate, poliitikast, haridussüsteemist ja meediast pärinevate kontseptsioonide ja narratiivide rekontekstualiseerimist ja teisendamist, aga ka tähendusloomet laiemas mõttes (de Cillia jt 1999). Peale poolavaliku, fookusrühmade intervjuukorpusest lähtuva diskursuse oleme analüüsinud, kuidas hindavad oma keeleoskust erinevas vanuses inimesed. Keele kestlikkuse seisukohast on põlvkondlik keeleülekanne ülioluline. Vanuselised või koguni põlvkondlikud erinevused hinnangutes keeleoskusele viitavad kas tugevamale või nõrgemale keeleülekandele või koguni keelevahetusele ja -kaole. Küsitlusandmete foonil näitame, kuidas intervjueeritavad seletavad keelekestlikkust ja -kadu, milliste teiste teemadega need teemad seostuvad.

\section{Küsitluste ja intervjuude andmed}

Kõigis neljas vaatluse all olevas keelekogukonnas toimusid välitööd üldjuhul samadel põhimõtetel ning sarnase metoodika alusel 2010. aasta kevadtalvel. Välitööde korraldamise põhimõtteid ja metoodikat on kirjeldatud kogukonnapõhistes raportites (Koreinik 2013a, 2013b, Praakli 2013a, 2013b).

Eestis Võru- ja Setumaal ning Soomes küsitleti rahvastikuregistrist tellitud esinduslikku valimisse juhuvaliku teel sattunud elanikke. Saksamaal raskendasid küsitluse korraldamist mitmed tegurid nagu Saksamaa range andmekaitseseadus, mis välistas projekti uurijatel saada rahvastikuregistripõhine terviklik ülevaade eesti keelt emakeelena rääkivate inimeste arvu, nende vanuse, soo ning paiknemise kohta. Seetõttu kasutati nii küsitluses kui intervjuudes osalejate leidmiseks nn lumepallimeetodit: kohalike eesti seltside ja sotsiaalmeedia abi ning uurijate isiklikke kontakte. Hoolimata mittetõenäosusliku valimi kasutamisest, annab Saksamaa valim üsna hea läbilõike Saksamaa eestlastest. Kuigi küsitluse korraldamise viisides oli kogukondade lõikes erinevusi (Soomes ja Saksamaal teostati postiküsitlus, Setu- ja Võrumaal kasutati küsitlejate abi), ei tohiks mõneti erineva metoodika abil saadud tulemustes suuri erinevusi olla (vt nt de Leeuw 2005). Eestis toimus küsitlus 1783.-1920. aastal eksisteerinud Võru maakonna ligikaudsetes piirides ${ }^{7}$ ja neljas setu elanikkonnaga tänapäeva vallas ${ }^{8}$. Soomes läbiviidud küsitlus hõlmas kogu Soomet tervikuna; Saksamaa puhul oli metoodikast johtuvalt enamik informante pärit

\footnotetext{
7 Tänapäeva Antsla, Haanja, Kanepi, Karula, Kõlleste, Laheda, Lasva, Meeksi, Mooste, Misso, Mõniste, Orava, Põlva, Räpina, Rõuge, Sõmerpalu, Taheva, Urvaste, Valgjärve, Vastseliina, Varstu, Veriora, Võru vald, Põlva linn ja Võru linn.

8 Meremäel, Mikitamäel, Missos ja Värskas. Missos küsitleti endise Pankjavitsa/Rootova valla külade elanikke.
} 
suurlinnadest ning eesti kogukondade keskustest. Saksamaal osales küsitluses 70, Soomes 171, potentsiaalsetest setu- ja võrukeelsetest vastavalt 294 ja 296 inimest.

Välitööde teiseks etapiks olid ühtsetel põhimõtetel läbiviidud temaatilised individuaal- ja fookusrühmaintervjuud. Kõikides uuritavates kogukondades toimusid intervjuud vanuserühmades 18-29, 30-49, 50-64 ning 65+ ning täiendavad intervjuud vähemusrühma aktivistide, enamusmeedia esindajate ning enamusrühma poliitikutega. Individuaalintervjuud koosnesid u 40, fookusrühmaintervjuud u 20 küsimusest.

Peatume artiklis detailsemalt nendel fookusrühma intervjuu küsimustel, mis on keelekestlikkuse ja -kao konstrueerimisel relevantseimad: kas vähemuskeelt on kaasaja ühiskonnas vaja; kes peaks vähemuskeele eest vastutama, ja miks; milline võiks olla vähemuskeele tulevik kümne aasta pärast?

\section{Tulemused}

\subsection{Küsitluste tulemused}

Keelekestlikkuse ja -kao diskursuse ilmestamiseks kasutame Saksamaa ja Soome eestlaste ning setu- ja võru keele kasutajate antud hinnanguid vastavate vähemus- ja enamuskeelte ning inglise keele kui vahendajakeele rääkimis- ja kirjutamisoskuste kohta (vt joonised 1-6). Rääkimis- ja kirjutamisoskust võib keele kestlikkuse ja kao seisukohast pidada olulisemaks keelekompetentsiks kui arusaamis- ja lugemisoskust, mida küsitluse käigus samuti hinnati. Keele osaoskusi mõõdeti viiepalliskaala (vabalt-hästi-mõnevõrra-halvasti-üldse mitte) abil. Respondentidel paluti märkida iga keele iga osaoskuse puhul, kuidas nad oma keeleoskust hindaksid. Selleks, et hinnata põlvkondlikke erinevusi osaoskuste lõikes, arvutati statistika tarkvara Statistical Analysis Software (SAS) abil aritmeetilised keskmised ja võrreldi neid eri valimite eri vanuserühmades. Dispersioonanalüüsi abil tehti kindlaks, kas vanuserühmade sisemine, s.t põlvkonnasisene osaoskuste hinnangute väärtuste hajuvus on seletatav valimi, s.t Saksamaa ja Soome eestlaste, võru ja setu keele kasutajate vastuste väärtuste üldise hajuvusega või on vanuserühmade vahel statistiliselt olulised $(p=0,05)$ erinevused. Joonistel oleme esitanud nelja vanuserühma hinnangute aritmeetilised keskmised. Erinevad üldkogumeid (ja valimeid) statistiliselt ei võrreldud.

Joonistelt 1-6 on näha, et eesti keele rääkimisoskust hinnatakse sihtrühmades enam-vähem sarnaselt. Ootuspäraselt hinnatakse paremaks suulist oskust. Saksamaa eestlastel puudusid põlvkondlikud erinevused mõlemas inglise keele osaoskuses. Soome eestlastel on olulised erinevused inglise keele rääkimises ja kirjutamises. Ühelt poolt on ilmselt selle põhjuseks sihtrühmade erinevad sotsiaalmajanduslikud näitajad (elukoht, vanus, sugu, haridus, sissetulek) ja küllap ka väljarände motiivid. Teisalt peab silmas pidama ka võõrkeeleõppe poliitikat Eestis. Kui näiteks soome keele aktiivse oskuse osakaal on Eesti elanikkonna hulgas kasvanud, siis saksa keele oskajate osakaal on alates 1934. a kuni millenniumivahetuseni püsinud stabiilne (Tender 2010). Võib oletada, et Saksamaale on välja rännanud pigem hea saksa ja inglise keele oskusega inimesed, Soome on mindud tööplaanidega ja ametitesse, kus vahendajakeelt ei nõuta. Noorema vanuserühma inglise keele oskuse hinnangud on üsna sarnased. 


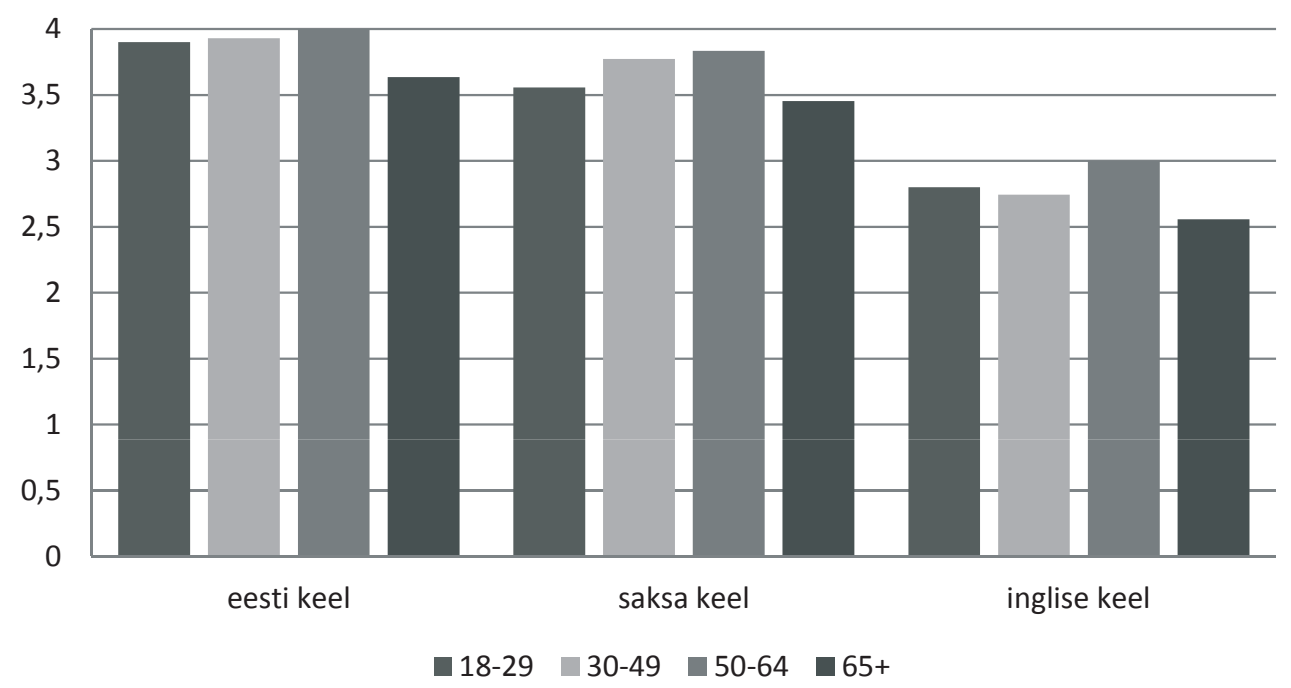

Joonis 1. Saksamaa eestlaste subjektiivne hinnang rääkimisoskuse kohta

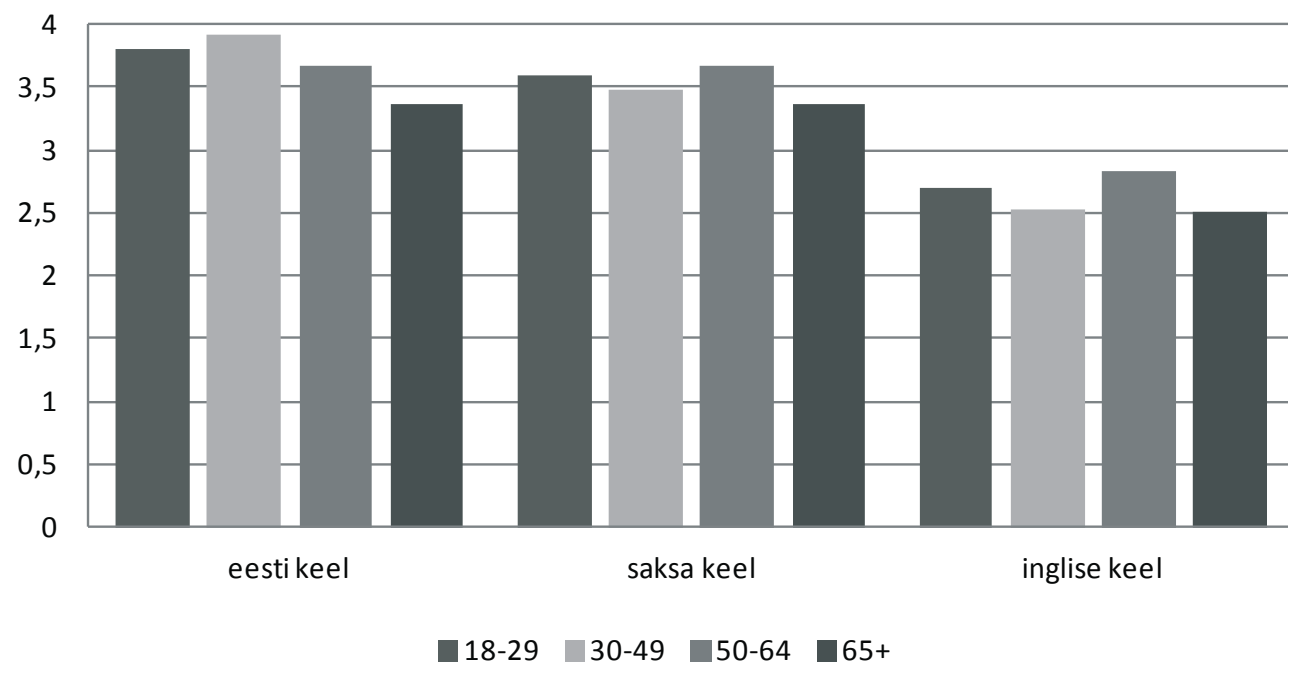

Joonis 2. Soome eestlaste subjektiivne hinnang rääkimisoskuse kohta

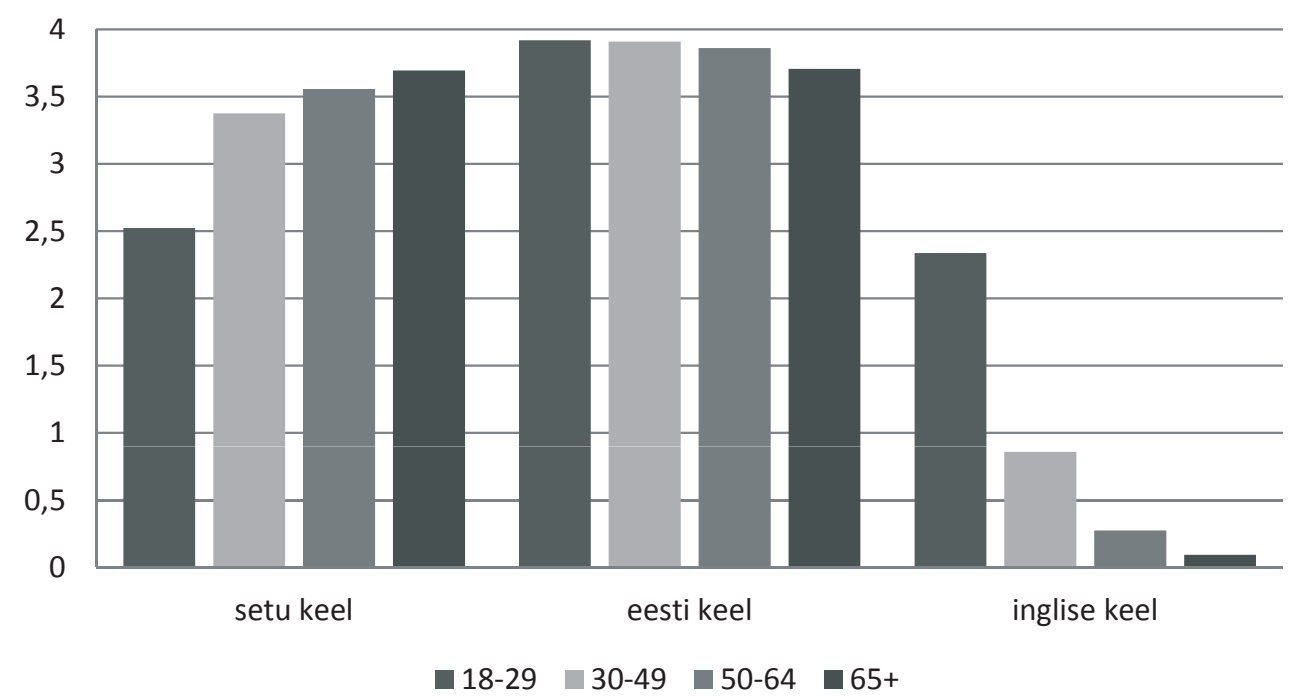

Joonis 3. Setu keele kasutajate subjektiivne hinnang rääkimisoskuse kohta 


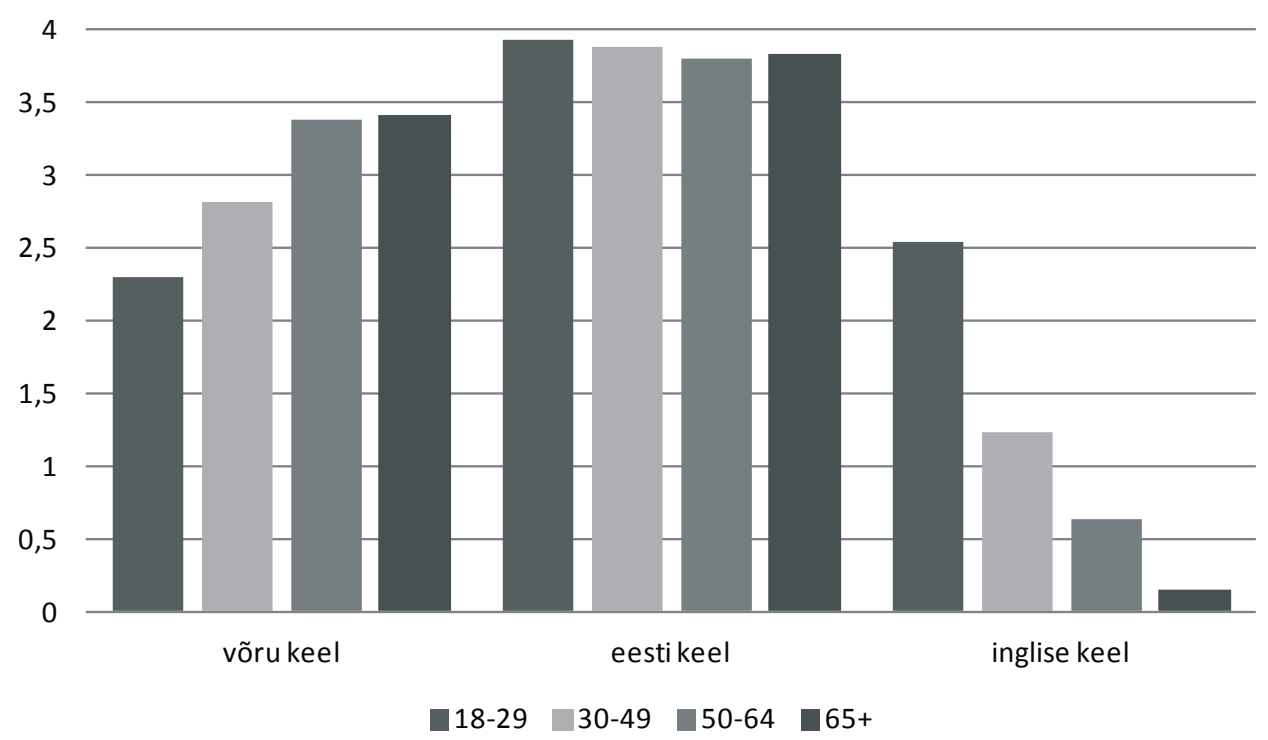

Joonis 4. Võru keele kasutajate subjektiivne hinnang rääkimisoskuse kohta

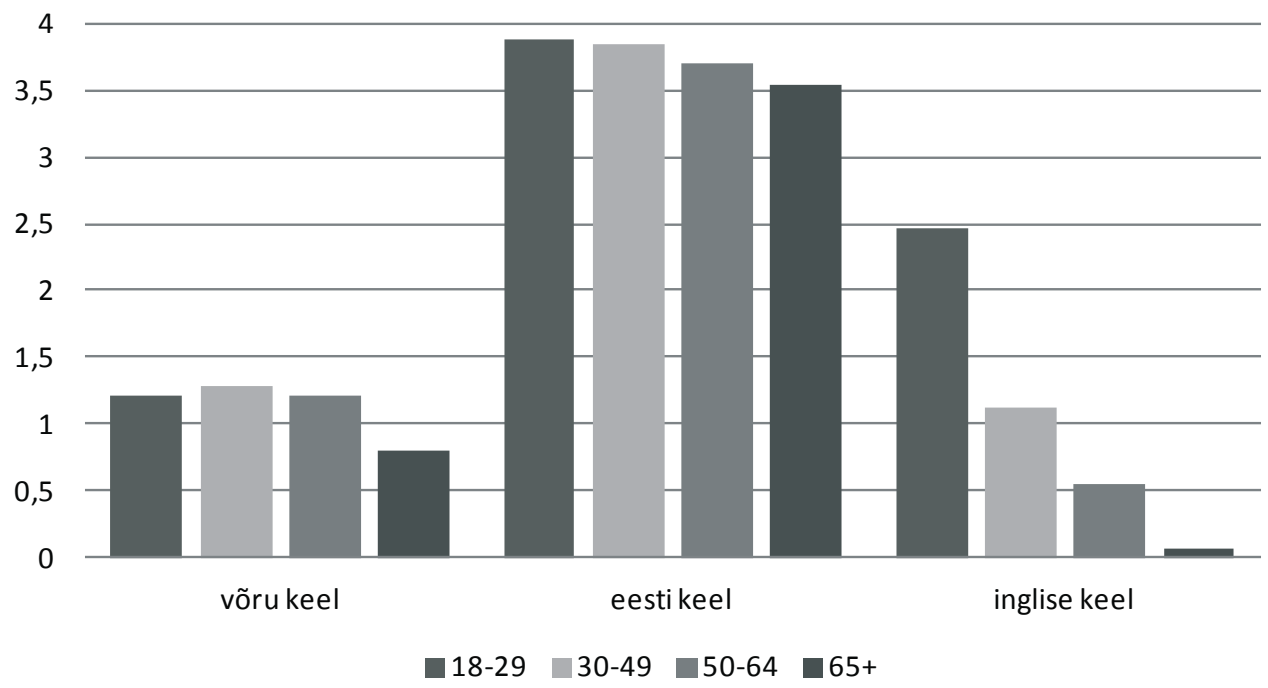

Joonis 5. Võru keele kasutajate subjektiivne hinnang kirjutamisoskuse kohta

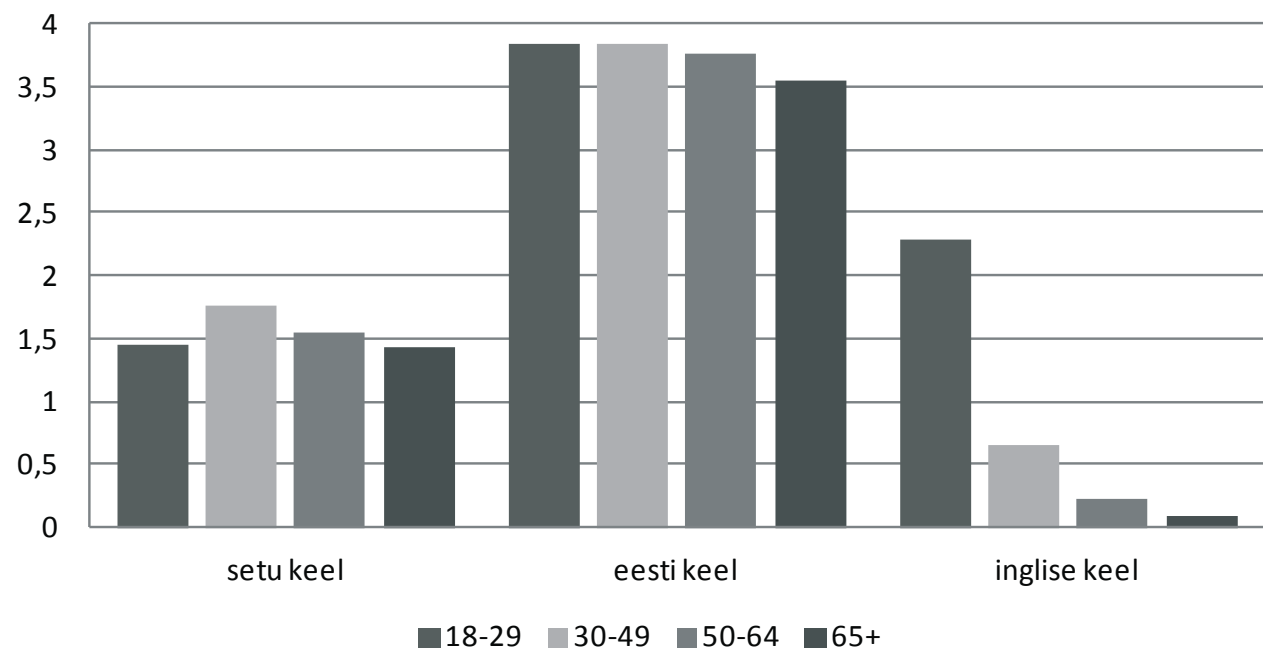

Joonis 6. Setu keele kasutajate subjektiivne hinnang kirjutamisoskuse kohta 
Setu ja võru keele rääkimisoskus on põlvkonniti erinev - noortel kehvem ja vanematel parem. Eesti keel on domineeriv keel (vt nt joonis 3 ja 4). Kirjutamisoskuses põlvkondlikke erinevusi pole, see osaoskus on ühtviisi kehv kõigil. Põhjusi võib otsida nii vähemus- kui enamuskeele funktsionaalses (diglossaalses?) eristamises, aga ühtlasi ka setu ja võru keele standardi piiratud levikus ning paraku ka kirjaviisivaidlustes. Ka inglise keele osaoskustes on selged põlvkondlikud erinevused: kõige noorem võru keele kasutajate grupp hindab inglise keele rääkimisoskust kõrgemalt kui võru keele oma.

\subsection{Intervjuude tulemused}

Avalikus diskursuses on tihtipeale teemaks olnud eesti keele ja kultuuri tugevdamine ja rikastamine (Koreinik 2011a). Selliseid mõttekäike leidub sageli ka poolavalikes diskursustes. Vastustest küsimusele, kas vähemuskeelt on kaasaja ühiskonnas üldse vaja, aimub ratsionaliseerivaid, põhjust ja tagajärge demonstreerivaid argumente (ingl rationalization). Seesugune argumenteerimisstrateegia johtub ühiskonna enamuse heakskiidetud normidest.

Enamuskeelte (saksa, soome, eesti) suhtes vähemuskeele positsioonis olevate keelte (vastavalt eesti, setu ja võru keel), aga ka laiemalt mitmekeelsuse funktsiooni nähakse suuresti eesti keele ja kultuuri ning Eesti majanduse, riigi ja ühiskonna rikastamises:

(1) --- noh ma arva et tuu tege eesti keelt kimmämbäs (VRO-AKTn)

(2) kui inemine kasus niiüteldä esi hindäst --- kiil om seotu identiteediga ja ku ta nigu saa-ai ennast avada --- vaba ja sääne loominguline inemine om ühiskonnale nigu (...) vajalik (SETO-AKTn)

Keele kestlikkust seotakse ka Eesti põlisasustuse ja/või -rahvastiku püsimisega. Mainitakse ka lojaalsust riigile ja Euroopa Liidu abi. Keelega seotud (kohalik) identiteet või keeleoskus võib osutuda Eesti kui terviku jaoks funktsionaalseks:

(3) jah tuu kiil hoit siin et sa ei lähe Austraaliahe (VRO-5064n)

(4) --- et euroopa raha tulõ selleperäst et mi jääsi iks siiä paika är ei lääsi sinna kos [!] noh lääneeuroopa põhjaeuroopa et olõmi siin visatas raha näpuotsaga --- ja tantske sääl oma kaerajaani või lööge leelot jääge iks umma kodokanti seepärast et noh lääneeuroopa om rahvast täüs (SETO-3049m)

Veel üks märkimisväärne ja ühtlasi rikastamisega seotud teema on keelelise mitmekesisuse otsene sidumine keelte turuväärtuse ja kaubastumisega (ingl commodification). Vähemuskeel kui erinevus võib kanda sümboolset väärtust, kuid sellel võib olla ka instrumentaalne väärtus (5).

(5) --- noh me tahame riigile ka lihtsalt kultuurilise kasu poolest (.) siis ka majanduslik kasu et mida rohkem omapära välja toome (.) seda suuremaks muutub ka turistide arv siia kanti --- (VRO-3049n)

Leidub ka teistsuguseid ratsionaliseerivaid argumente. Kollektiivi, ühiskonna ja/või riigi asemel on argumentatsiooni keskmes indiviid ning mitmekeelsuse 
funktsionaalsus, aga ka vähemus- või vahendajakeel indiviidi seisukohast. Näide (7) illustreerib ühtlasi Eesti väiksuse diskursust.

(6) --- see lihtsalt rikastab inimest (.) see on ikkagi nagu mõnes mõttes selline kahe tausta olemasolu kahe- (...) kultuuri (.) olemasolu (GER-3049n)

(7) --- ma tean et kui need keeled ((inglise ja saksa)) on juba lapsest peast suus sa võid (.) maailmas nagu igal pool läbi lüia et just see et eesti on nii väike et see ei ole lissalt praktiline selles suhtes (GER-1829n)

(8) no mina mõtlen puht pragmaatiliselt --- see oleks nagu selles mõttes kingitus et see on nagu (.) üks aken veel mis on sinu ees lahti kui perfektselt sa seda sis valdad --- ma lähtun iseendast et (.) mina tahaksin olla mitmekeelne (GER-3049n)

(9) aga piässi toda kuigi nigu soodustama või miilde tulõtama õks või vanavanõmbitele ka et et et no kotun kasutagõ toda kiilt ja tuu rikastas latsõlatsi mitte ei tii näid ullikõsõst (SETO-5064m)

Küsimusele Kes peaks üldse vastutama vähemuskeelte eest? antud vastused jagunevad ootuspäraselt kaheks: ühed asetavad keelte kestlikkuse vastutuse kogukonnale, ühiskonnale ja/või riigile (11-18), teised näevad vähemuskeelt kasutavat indiviidi ennast vastutajana $(10,17-18)$.

(10) mina isiklikult ütleks alati et see $=\mathrm{n}$ täitsa inimese (.) ((natuke naerdes)) $\mathrm{sa}=\mathrm{i}$ saa sundida? inimest rääkima ema- emakeeles kui ta = i taha ((kui ei taha)) siis ärgu rääkigu (GER-65+n)

(11) --- eks ikka eest- eestlased ise (FIN-1829m)

(12) aga perele ma arvan peaks toeks olema siis see emariik (FIN-5064n)

(13) --- riigi ülesannne peaks olema see ((setu)) et see ära ei kaoks et see ikka nagu jääks püsima siia (SETO-1829m)

(14) no riik üleüldse iks vastutas uma elanike iist ja selle kultuuri iist mis tan om sis õks järelikult (.) kuna kuna mi olõmi ka üts osa sellest riigist (VRO-AKTn)

(15) mina arvan et eesti (.) ee vata (.) kui eesti ise tunneb huvi (.) oma (.) aa nende alluvate vastu siis on ee ja ta (.) ta tunneb huvi ja ta tahab et ee kõigil eestlastel $\mathrm{m}$ - laias ilmas hea on siis ma arvan see keel iseenesest säilib (.) ma arvan et ee vata kui seal kus on ü- (.) hea soe ja mu- mugav (.) ja mõnus olla s- sinna tahad tagasi ja ma arvan k- keelega on täpselt samamoodi kui (.) eestis on hea ja mugav ja mõnus olla si = se keel tahab kõik sinna tagasi ja sis ta seal säilib kah (GER-3049m)

(16) --- see on tõesti eesti rahva enda teha kas ta tahab jääda elujõuliseks (.) nii nagu ta on (.) aastasadu olnud või tahab ta lihtsalt alla minna [!] ja kaotada oma identiteedi --- (GER-65+m)

(17) aga mi olõmigi mi olõmigi tuusama ütiskund (.) mi olõmigi tuu kes kes toda kes tuu vastutusõ omgi võtnu et mi kõnõlõmõ võru kiilt ja tuu et mu latsõlatse ja ma kõnõlõ nä kõnõlõsõ muga kirjakeelen a mina kõnõlõ 
neidega [!] aja ikka [!] umma joru ja ja na saava väega häste arvu ja latsõ omma ka nakanu nüüd kolmekümne aastaselt omma nakanu nüüd rohkõmp võru kiilt pruukma (VRO-5064m)

(18) eestlasi võib-olla siis juba (.) eesti poolt see eesti instituut kes sis organiseerib kes on selline nagu natuke ametlikum (...) organisatsjoon kes võib-olla korraldab üritusi ja toob inimesed kokku aga (.) kui eestlased ise ei räägi sis ega eesti instituut ka sinu eest rääkima ei akka (FIN-1829n)

On ka neid informante, kes näevad keeleökoloogilisi protsesse, sh keele kestlikkust ja kadu kui iseeneslikku ja paratamatut protsessi, kus puuduvad toimijad või keelekasutajal puudub agentsus (vrd Koreinik 2011b):

(19) tiiät külh et hulka pallo suurõmbit kiili om lännu nisamute (VRO-5064m)

(20) --- ma arvan et see keel nagu (...) püsib ise siin ((Soomes)) ja ja nagu ise reguleerib end (FIN-1829m)

(21) eriti siis kui elatakse väga kaua välismaal sa tunned ennast mõnikord ku- tud- kui sa tunned et teised keeled (...) saavad ikka (.) dominantsemaks aga sinu enda keel (...) lissalt (.) natukene (.) lissalt (.) saab ikka väiksemaks nii-öelda (GER-3049n)

(22) --- ma arvan et kõige suurem nagu probleem ongi see et siis kui tuleb nagu erinevaid igasuguseid uusi keeli peale kas või mingi inglise ja vene noh mis iganes siis nagu kaovadki need murded ära ja ja võibolla lõpuks hajub see eesti keelgi ära kui siin kõik räägivad hoopis teist asja (SETO-1829n)

Keelte ja etnoste olemuslikku (ingl essentialist) sisu ja seost rõhutavad järgmised seletused (explanation). Informantide hinnangul tagab etnose püsimine ja vähemusrahvuse kasv asukohariigis automaatselt ka keele kestlikkuse (23-25).

(23) tuleb (.) ästi palju eestlasi teha (FIN-1829n)

(24) --- ma arvan et ee eesti keel eks ta säilib ikkagi nii kaua (.) kui siin eestlasi on --- (GER-AKTn)

(25) no nikavva neid ku om setu nikavva om ka kiil (SETO-65+n)

Ühtlasi seostatakse keelevahetust mobiilsuse, sotsiaalse hierarhia ja prestiižiga (26).

(26) ku tuu üle pruuvi (.) nii perrä mõtõlda et määne tuu aig oll sääl määnegi pääle sõta kohkilgi vai et nuu kiä lätsi säält küläst vällä kohegi kavvõmbahe nuu ope määndsegi aameti (.) korssiva kuulsust ja ku nuu tulli küllä tagasi (.) sis näil oll tuu võõra keele mõotuse mano jäänü (.) ja noile kiä sis sääl iks lehmaperse takah sitta vissiva (.) nisast piimä tõmpsiva noile tundu tuu oi kae tuu om tark miis kae kus tä kõnõlõs ja sis nu väiku tatika nuu sändse jah kaiva vot vaja perrä tetä (VRO-5064m)

Mis juhtub keelega kümne aasta pärast? Arvamusi on seinast seina. Keele kestlikkust ja kadu põhjendatakse mitmesuguseid diskursiivseid skeeme, näiteks võrdlust (27-29) ja seletust (30-31) kasutades. Viimane (31) on ühtlasi näide keele ja etnose olemuslikust seostamisest. 
(27) mina arvan et rohkem aina ära kaob ja rohkem ja rohkem ee (.) ee lapsed hakkavad soomestuma --- siis sellel keelel mingit tulevikku siin ei ole (FIN-AKTn)

(28) ja kui kaos ära tegelikult tuu põlvkond kes omma parhilla pensionääri et kui tuu põlvkond ära häos ja ja mi pääle kasume et kas mi oleme siis nagu võro kiilt kõnõleva vanaimä ja vanaisä [!] (VRO-1829n)

(29) õõ (...) selle võrra näiteks et kui nüüd eestis kümne aasta pärast õõ majandus tõusma akkab et = sis näiteks (.) eestlased lähevad rohkem sinna tagasi ja ja jääb siia vähem näiteks õõ (FIN-1829m)

(30) ta jääss viil aastakümnetest kindlästi seepäst et siin kiräsõnah om väega pallo seda ja ja taa avitas veidkene edesi venütädä ja tekis iks säändsit kes tahtva oppi toda ja ja ja edesi kanda ja nii et ta kandus edesi aga mitte suurõ ei suurõnõ (...) tsutt väiksembäst [!] iks jääs (SETO-5064m)

(31) ((olen)) ennast eestlaseks pidanud ja soomlaseks samal ajal kolgend aastat laululaval laulnud = ja ma arvan et see ei kao kuskile --- (FIN-5064n)

Hoolimata sellest, et mitmed informandid näevad peamise vastutajana riiki, mainiti mitmel juhul põlvkondlikku keeleülekannet või selle puudumist (32-35).

(32) --- väga palju on tegelikult inimesi ju (.) noh (.) tändab meie vanuse grupist kel on lapsed ja nad räägivad oma lastega (...) saksa keeles (GER-3049n)

(33) --- mul klassisõsar tuu ütel ka et et et noh om kõik seto lauluimä ja kõik mis tä om aga kotun ütles et ma kõnõlõ küll jah seto keelen aga na kõnõlõsõ mullõ õks eesti keelen vasta (.) latsõlatsõga (SETO-5064m)

(34) et see (.) see ongi ju nagu see mida vanemad laps- (.) lastele edasi annavad et see on see et sa tead kus = sa tuled ja kus = sa pärit oled ja mis on nagu peres tähtis --- ma = i kujuta jälle ette et $=$ et et kui on ee kaks erinevat ee kultuuri need saavad kokku ja siis akatakse elama ainult nagu ühe kultuuri traditsioonide järgi et see oleks (...) noh (.) selgelt teise (.) teise jah nagu maha surumine (GER-3049n)

(35) latsõlõ või tulla tuu om rassõ asi ku lats ei kõnõlõ tedä ja sa panet talle määndsegi lisakoormuse sinnä otsa viil tolle võru keele --- (VRO-5064m)

Keele tulevikust rääkides peatuti inglise keele domineerimisel - seda mainisid mitmel korral Setu informandid. Muudest teemadest võib esile tõsta kaht: sooline aspekt põlvkondlikus keeleülekandes ning purism. Kui sooline aspekt tõstatub eeskätt Soome ja Saksamaa eestlaste diskursuses, kus keele peamise säilitajana nähakse naist/ema, ei saa ühe meeskeelejuhi (Saksamaa) hinnangul mööda vaadata ka meeste rollist peresiseste keelevalikute puhul. 


\section{Kokkuvõte}

Keele kestlikkuse ja kao diskursuses peegelduvad ühiskonnas eksisteerivad keelega seotud representatsioonid, keeleideoloogiad. Keeleideoloogiad omavad suuremat tähtsust (ennekõike poliitilist) kui keelelised faktid (Cameron 2006). Keelelistest representatsioonidest moodustub nn hierarhia-diskursus (Hult 2010), kus erinevaid keeli ja keelekasutajaid positsioneeritakse erinevat väärtust omavatena. Siinses uurimuses analüüsisime keelekestlikkuse ja -kao diskursust kvalitatiivselt, nii pole võimalik välja tuua keelekogukondade vahelisi arvulisi erinevusi. Siiski joonistuvad välja mõned tüüpilised teemad ja argumendid, mida kasutasid ühe keelekogukonna informandid, teised aga mitte.

Vähemuskeele funktsiooni nähakse peamiselt eesti keele ja kultuuri, aga ka ühiskonna, riigi ja majanduse rikastajana. Uuringus osalenud informantidest tõstsid viimase argumendi esile eeskätt Soomes elavad eestlased. Ka setu ja võru keele kasutajad nägid oma keelte rolli eesti keele ja kultuuri rikastamises, ent majanduslik argument ei jäänud mainimata neilgi. Nemad rõhutasid ka tugeva (keelelise) identiteediga seotud paiksuse väärtuslikkust Eesti riigi (asustuse, rahvastiku kestlikkus) ja eesti kultuuri seisukohast.

Kõnekaks erinevuseks Soome ja Saksamaa eestlaste vahel on mitmekeelsuse (ka vahendajakeele) roll indiviidi seisukohast. Küllap on see seletatav keelekogukonna kujunemise tausta ning keelekogukonna eripäradega laiemas mõttes. Kuigi uuringus osalenud Soome ja Saksamaa eestlasi võib nimetada esimese põlvkonna sisserännanuteks, kes esindavad mõlemas riigis suhteliselt uut ja noort keelelist vähemusrühma, on kogukonnad ELDIA tulemuste põhjal sotsiodemograafiliselt vägagi erinevad. Saksamaa eestlased on ülekaalukalt kõrgharidusega naised, kel on hea ühiskondlik positsioon ning erialased eneseteostusvõimalused. Soome eestlaskond on tunduvalt heterogeensem. Saksamaa eestlasi iseloomustab selge mitmekeelne identiteet, kus eesti keele kõrval peetakse oluliseks vähemalt kahte keelt - uue asukohariigi enamuskeelt ehk saksa keelt ning inglise keelt kui vahendajakeelt (see nähtub ka informantide subjektiivsetest hinnangutest saksa ja inglise keele oskuse, kasutusalade ja -sageduse kohta). Informantide hoiakus inglise keele suhtes võib näha teatavat pragmaatilisust: inglise keel on maailmakeel, mille valdamist peetakse enesestmõistetavaks, sest seda vajatakse etnostevahelises suhtluses ning tööülesannete täitmises. Samas ei nähta inglise keelt võimaliku kodukeelena eesti keele asemel või ühe keelena eesti keele kõrval.

Kõigis keelekogukondades nähakse keele kestlikkuse eest vastutajana üksikindiviidi ja riiki. Soomes ja Saksamaal elavate eestlaste silmis on nende uue asukohariigi roll eesti keele kestlikkuse osas siiski marginaalne. Olukord on mõneti erinev Soome puhul, kus eestlaste jätkuvale intensiivsele töörändele viidates lasub keelejuhtide sõnul eesti keele kestlikkuse eest vastutamise kohustus ka Soome riigil. Üldistavalt öeldes: kui Eesti riigi rollis nähakse eeskätt moraalselt ning finantsilist toetust, siis Soomelt oodatakse toetust eestikeelsete haridusvõimaluste loomiseks.

Mis saab nendes kogukondades eesti, võru ja setu keelest lähitulevikus? Püüdes kokku võtta keelekogukondade kohta varem avaldatu ning küsitlus- ja intervjuutulemused, võib teha järgmised ettevaatlikud järeldused. Setu ja võru keelekogukonnad on jõudnud keelevahetuse lõppfaasi. Setu ja võru keele kirjutamisoskust on hinnatud madalalt kõigis vanuserühmades. Uus nn Võro-Seto standard pole kuidagi 
suutnud eesti kirjakeele positsiooni kõigutada, mõjudes kirjutamisel ilmselt nii ideoloogilise kui tehnoloogilise barjäärina. Tõenäoliselt on standardi levikule oma jälje jätnud ka kirjaviisivaidlused. Säilinud on kõnekeele oskus, kuigi nooremad põlvkonnad annavad sellele madalama hinde. Keelekestlikkuse ja -kao diskursustes nähakse võru ja setu keele rolli tüüpiliselt eesti keele ja kultuuri rikastamises (vrd Koreinik 2011a). Üldjuhul ei omistata vähemuskeeltele utilitaarset turuväärtust, mistõttu nägid vaid üksikud keelejuhid neid indiviidi rikkuse, mitmekeelsuse osana. Keele kestlikkus või kadu on nii riigi/ühiskonna (organisatsioonide) kui keelekasutaja (perekonna) vastutusel. Keelekadu representeeritakse ka ilma toimijateta, s.t kui midagi iseeneslikku, sageli kui paratamatut (vrd Koreinik 2011b). Mainimata ei saa jätta puristlikke seisukohti, mis siin-seal esile tõusid (vrd Raag 1999).

Saksamaa ja Soome eestlaste puhul on keelevahetusest vara rääkida, kuna mõlema keelekogukonna näol on tegu kujunemisjärgus oleva rühmaga. Oluline on rõhutada, et nendegi argumentatsioon jääb keelelise ja kultuurilise rikastamise raamistikku. Tähelepanu väärivad ühtlasi keele ja etnose olemuslikke seoseid näitavad diskursiivsed praktikad. Nii näiteks püsib eesti keel Saksamaal ja Soomes seni, kuni kestab eestlaste väljaränne nimetatud riikidesse. Inglise keele võimalikus domineerimises eesti keele tulevikule ohtu ei nähta. Eestlaste keelelisi õigusi Saksamaal ja Soomes ei mainitud. Eesti keele toetamist nähakse Eesti riigi ja indiviidi enda kohustusena.

Toetudes Jan Blommaerti, Jan Collinsi ja Stef Slembroucki (2005: 213) mõttele, mille järgi pole mitmekeelsus indiviidide omadus või selle puudumine, vaid keskkond, mis struktureerib indiviidide keelelisi valikuid ja interaktsioone, võib väita, et keeleideoloogiatel on selle keskkonna loomisel oluline roll. See, kas ühiskond ja keelepoliitikad toetavad mitmekeelsust ja millised keeled on igas ühiskonnas defineeritud mitmekeelsusena, määrab muude faktorite kõrval vähemuskeelte kestlikkuse.

\section{Lühendid ja sümbolid}

$\begin{array}{ll}--- & \text { väljajätt } \\ (()) & \text { täpsustavad kommentaarid } \\ (.) & \text { lühike paus } \\ (\ldots) & \text { pikk paus } \\ ? & \text { tõusev intonatsioon } \\ {[!]} & \text { keelenäidetele viitamine } \\ 1829 & 18-29 \text {-aastaste fookusrühm } \\ 3049 & \text { 30-49-aastaste fookusrühm } \\ 5064 & \text { 50-64-aastaste fookusrühm } \\ 65+ & \text { 65-aastaste ja vanemate fookusrühm } \\ \text { AKT } & \text { aktivistid } \\ \text { FIN } & \text { Soome eestlased } \\ \text { GER } & \text { Saksamaa eestlased } \\ \text { m } & \text { meesinformant } \\ \text { n } & \text { naisinformant } \\ \text { saks- } & \text { pooleli jäänud sõna } \\ \text { SETU } & \text { setu keele kasutajad } \\ \text { VRO } & \text { võru keele kasutajad }\end{array}$




\section{Viidatud kirjandus}

Abell, Jackie; Myers, Greg 2008. Analyzing research interviews. - Ruth Wodak, Michał Krzyżanowski (Eds.). Qualitative Discourse Analysis in the Social Sciences. New York: Palgrave, Macmillan.

Annist, Aet 2009. Outsourcing culture: Establishing heritage hegemony by funding cultural life in South Eastern Estonia. - Lietuvos etnologija - Socialines antropologija i etnologija studij, 9, 117-138.

Blackledge, Adrian 2005. Discourse and Power in a Multilingual World. Philadelphia: John Benjamins Publishing Company.

Blommaert, Jan; Collins, Jan; Slembrouck, Stef 2005. Spaces of multilingualism. - Language \& Communication, 25 (3), 197-216. http://dx.doi.org/10.1016/j.langcom.2005.05.002

Cameron, Deborah 2006. Ideology and language. - Journal of Political Ideologies, 11 (2), 141-52. http://dx.doi.org/10.1080/13569310600687916

Cenoz, Jasone; Gorter, Durk 2005. Trilingualism and minority languages in Europe. - International Journal of the Sociology of Language, 171, 1-5. http://dx.doi.org/10.1515/ ijsl.2005.2005.171.1

Cenoz, Jasone; Gorter, Durk; Heugh, Kathleen 2011. Linguistic diversity. - Dafne C. Reymen, Steven Knotter (Eds.). Glossary on Diversity. Sussex: Sussex Academic Press, 83-98.

de Cillia, Robert; Reisigl, Martin; Wodak, Ruth 1999. The discursive construction of national identities. - Discourse \& Society, 10 (2), 149-173. http://dx.doi.org/10.1177/09579 26599010002002

de Leeuw, Edith D. 2005. To mix or not to mix data collection modes in surveys. - Journal of Official Statistics, 21 (2), 233-255.

Ehala, Martin 2010. Refining the notion of ethnolinguistic vitality. - International Journal of Multilingualism, 7 (4), 363-378. http://dx.doi.org/10.1080/14790711003637094

Eichenbaum, Külli 1998. Ku kavvas Setomaalõ seto rahvast jakkus? - Võro Instituudi toimetused/Võro Instituudi Toimõndusõq 2. Võro: Võro Instituut, 11-15

Eichenbaum, Külli; Pajusalu, Karl 2001. Setode ja võrokeste keelehoiakutest ja identiteedist. - Keel ja Kirjandus, 7, 483-489.

Fairclough, Norman. 1989. Language and Power. London: Longman.

Ferguson, Charles A. 1977. Sociolinguisic settings of language planning. - Joan Rubin, Bjorn H. Jernudd, Jyotirindra Das Gupta, Joshua A. Fishman, Charles A. Ferguson (Eds.). Language Planning Processes. The Hague: Mouton, 9-30.

Fishman, Joshua A. 2001. Reversing Language Shift. Theoretical and Empirical Foundations of Assistance to Threatened Languages. Clevedon: Multilingual Matters.

Hornberger, Nancy; Hult, Francis M. 2008. Ecological language education policy. - Bernard Spolsky, Francis M. Hult (Eds.). Handbook of Educational Linguistics. Malden, MA: Blackwell, 280-296.

Hult, Francis M. 2010. Analysis of language policy discourses across the scales of space and time. - International Journal of the Sociology of Language, 202, 7-24. http://dx.doi. org/10.1515/ijsl.2010.011

Johnson, David C. 2009. Ethnography of language policy. - Language Policy, 8 (2), 139-159. http://dx.doi.org/10.1007/s10993-009-9136-9

Jørgensen, Marianne; Phillips, Louise 2002. Discourse Analysis as Theory and Method. London, Thousands Oaks, New Delhi: Sage Publications.

Koreinik, Kadri 2011a. Language ideologies in the contemporary Estonian public discourse: With a focus on South Estonian. Dissertationes sociologicae Unversitatis Tartuensis 5. Tartu: Tartu Ülikooli Kirjastus.

Koreinik, Kadri 2011b. Agency lost in the discourse of language endangerment: Nominalization in discourse about South Estonian. - Eesti Rakenduslingvistika Ühingu aastaraamat, 7, 77-94. http://dx.doi.org/10.5128/ERYa7.05 
Koreinik, Kadri (ilmumas 2013a). Case-specific report on the Seto language. With contributions by Eva Kühhirt, Anneli Sarhimaa, Sia Spiliopoulou-Åkermark, and Reetta Toivanen. ELDIA Working Papers.

Koreinik, Kadri (ilmumas 2013b). Case-specific report on the Võro language. With contributions by Eva Kühhirt, Anneli Sarhimaa, Sia Spiliopoulou-Åkermark, and Reetta Toivanen. ELDIA Working Papers.

Krikmann, Arvo 2000. Tere teele, tere meele, tere egalõ talõlõ. Valik lõunaeesti mõistatusi. Tartu: Eesti Kirjandusmuuseum.

Kyntäjä, Eve 1997. Eestlased Soomes - akulturatsioonipsühholoogia ja etniline identiteet. Hill Kulu, Katrin Metsis, Tiit Tammaru (Toim.). Eestlane olla ... Eesti keele ja kultuuri perspektiivid. Tartu: Tartu Ülikooli Kirjastus, 60-71.

Laanekask, Heli 2006. Virolaiset Suomessa suomenvirolaisiksi. - Olga Haurinen, Helena Sulkala (Toim.). Tutkielmia vähemmistökielistä Jäämereltä Liivinrantaan. Vähemmistökielten tutkimus- ja koulutusverkoston raportti V. Universitatis Ouluensis, Acta B, Humaniora B 69. Oulu: Oulun yliopisto, 55-73.

Maffi, Luisa 2000. Language preservation vs. language maintenance and revitalization: Assessing concepts, approaches and implications for language sciences. - International Journal of the Sociology of Language, 142, 175-190. http://dx.doi.org/10.1515/ ijsl.2000.142.175

McCarty, Theresa (Ed.) 2011. Ethnography and Language Policy. New York, London: Routledge.

Mufwene, Salikoko S. 2008. Language Evolution: Contact, Competition and Change. London, New York: Continuum.

Myers-Scotton, Carol 2002. Contact Linguistics. Bilingual Encounters and Grammatical Outcomes. Oxford: Oxford University Press.

Org, Ervin; Reimann, Nele; Uind, Katrin; Velsker, Eva; Pajusalu, Karl 1994. Vastseliina Sute küla elanike murdepruugist ja keelehoiakutest. - Keel ja Kirjandus, 4, 203-209.

Pajusalu, Karl 2007. Estonian Dialects. - Mati Erelt (Ed.). Estonian Language. 2nd ed. Tallinn: Estonian Academy Publishers, 231-272.

Pajusalu, Karl; Velsker, Eva; Org, Ervin 1999. On recent changes in South Estonian: Dynamics in the formation of the inessive. - International Journal of the Sociology of Language, 139, 87-103. http://dx.doi.org/10.1515/ijsl.1999.139.87

Pajusalu, Karl; Hennoste, Tiit; Niit, Ellen; Päll, Peeter; Viikberg, Jüri 2002. Eesti murded ja kohanimed. Tallinn: Eesti Keele Sihtasutus.

Praakli, Kristiina 2007. Eesti keele kasutusväljad Tampere eesti kogukonna näitel. - Pirkko Muikku-Werner, Ossi Kokko, Hannu Remes (Toim.). Suomalais-ugrilaisia kohdekieliä ja kontakteja. VIRSU III. Studies in Languages 42. Joensuu: Joensuun yliopisto, 91-105.

Praakli, Kristiina 2009. Esimese põlvkonna Soome eestlaste kakskeelne keelekasutus ja koodikopeerimine. Dissertationes philologiae estonicae Universitatis Tartuensis 24. Tartu: Tartu Ülikooli Kirjastus.

Praakli, Kristiina 2013a (ilmumas). Case-specific report on Estonian language in Germany. With contributions by Eva Kühhirt, Anneli Sarhimaa, Sia Spiliopoulou-Åkermark, and Reetta Toivanen. ELDIA Working Papers.

Praakli, Kristiina 2013b (ilmumas). Case-specific report on Estonian language in Finland. With contributions by Eva Kühhirt, Anneli Sarhimaa, Sia Spiliopoulou-Åkermark, and Reetta Toivanen. ELDIA Working Papers.

Raag, Raimo 1999. One plus one equals one: The forging of Estonian Standard. - International Journal of the Sociology of Language, 139, 17-38. http://dx.doi.org/10.1515/ ijsl.1999.139.17

Ricento, Thomas; Hornberger, Nancy 1996. Unpeeling the onion: language planning and policy and the ELT professional. - TESOL Quarterly, 30 (3), 401-428. http://dx.doi. org/10.2307/3587691 
Saar, Evar 2003. Setos - Eine südestnische Sprache und Kultur an der Estinisch-Russischen Grenze. - Wolfgang Brücher (Hrsg.). Grenzverschiebungen. Interdisziplinäre Beiträge zu einem zeitlosen Phänomen. Internationales Symposium des interdisziplinären Forschungsschwerpunktes "Grenzregionen und Interferenzräume" der Philosophischen Fakultäten der Universität des Saarlandes in Saarbrücken und Forbach 10.-12. Mai 2001. Röhrig Universitätsverlag, 103-118.

Silverstein, Michael 1979. Language structure and linguistic ideology. - Paul R. Clyne, William F. Hanks, Carol F. Hofbauer (Eds.). The Elements: A Parasession on Linguistic Units and Levels. Chicago: Chicago Linguistic Society, 193-247.

Special Eurobarometer 386 = Europeans and Their Languages. Report. June 2012. http:// ec.europa.eu/public opinion/archives/ebs/ebs 386 en.pdf (03.01.2013).

Spolsky, Bernard; Shohamy, Elana 200o. Language practice, language ideology, and language policy. - Richard D. Lambert, Elana Shohamy (Eds.). Language Policy and Pedagogy. Essays in honor of A. Ronald Walton. Amsterdam, Philadelphia: John Benjamins Publishing Company, 1-42.

Tender, Tõnu 2010. Mitmekeelsus Eestis Euroopa Liidu mitmekeelsuse ideaali taustal. Dissertationes de mediis et communicationibus Universitatis Tartuensis 9. Tartu: Tartu Ülikooli Kirjastus.

van Dijk, Teun A. 2005 [1998]. Ideoloogia. Multidistsiplinaarne käsitlus. Tartu: Tartu Ülikooli Kirjastus.

van Leeuwen, Theo J.; Wodak, Ruth 1999. Legitimizing immigration control: a discoursehistorical analysis. - Discourse Studies, 1 (1), 83-119. http://dx.doi.org/10.1177/14 $\underline{61445699001001005}$

\section{Võrgumaterjalid}

DESTATIS. Statistisches Bundesamt. Pressemitteilung Nr. 355 vom 26.09.2011. https://www. destatis.de/DE/PresseService/Presse/Pressemitteilungen/2011/o9/PD11 355122. html (06.07.2012).

ELDIA. European Language Diversity for All. http//:www.eldia-project.org (18.02.2013).

Pravitel'stvo Rossijskoj Federacii. Postanovlenie ot 24 marta 2000 g. N 255. O edinom perečne korennyh maločislennyh narodov Rossii. http://www.minnac.ru/minnac/ info/13884.html (03.03.2013).

RELO7 = Eesti emakeelega püsielanikud, 31. detsember 2011 --- murdekeele oskus ning sugu. http://pub.stat.ee/px-web.2001/Dialog/varval.asp?ma $=$ RLE07\&lang $=2$ (06.09. 2012).

Statista. http://de.statista.com/statistik/daten/studie/1221/umfrage/anzahl-der-auslaenderin-deutschland-nach-herkunftsland/ (06.07.2012).

Tilastokeskus. www.stat.fi (30.09.2012).

Kadri Koreinik (Tartu Ülikool, Võru Instituut) on sotsioloog, kelle peamine uurimishuvi on keeleideoloogiad ja diskursusuuringud.

kadri.koreinik@ut.ee

Kristiina Praakli (Tartu Ülikool) on erialalt eesti filoloog. Tema peamised uurimisteemad on väliseesti keel ja keelekontaktid.

kristiina.praakli@ut.ee 


\title{
THE CONSTRUCTION OF LANGUAGE MAINTENANCE AND LOSS IN SEMI-PUBLIC DISCOURSES
}

\author{
Kadri Koreinik ${ }^{1,2}$, Kristiina Praakli ${ }^{1}$
}

${ }^{1}$ University of Tartu, ${ }^{2}$ Võro Institute

The paper presents an analysis of the construction of language maintenance and loss in semi-public discourses of Estonians living in Germany and Finland, and of Setu and Võru speakers. The data was gathered by the international interdisciplinary project European Language Diversity for All, which focuses on speakers of small or less used Finno-Ugric languages in contemporary multilingual societies. Estonians living in Germany and Finland represent allochthonous language communities, whereas Setu and Võru speakers form autochthonous Estonian speech communities; the demarcation between the two groups is somewhat problematic. All of the speech communities consist of multilingual Estonians who have managed to maintain their minority languages to a lesser or greater extent in majority language contexts, i.e. in German, Finnish and Estonian language environments. Besides discourse analysis, the self-reported language competences of people of different ages are briefly analysed. The discourse of language maintenance and loss can be seen as a discourse of legitimation, where arguments about the functions and futures of minority languages are expressed. One of the explicit results is that all informants remain within the framework of linguistic, cultural or economic enrichment, without considering linguistic rights.

Keywords: minority language, majority language, vehicular language, language communities, discourse studies, language ideology, language ecology, Estonian, English 